\title{
MEMORIZATION IN DSS, NT, TALMUD AND PATRISTIC DOCUMENTS
}

\author{
Philip Suciadi Chia'), Juanda ${ }^{2)}$ \\ 1) Southern Baptist Theological Seminary - Kentucky USA \\ E-mail: pchia275@students.sbts.edu \\ 2) Evangelical Theological Seminary of Indonesia - Surabaya \\ E-mail: juanda@sttii-surabaya.ac.id
}

\begin{abstract}
The history of civilization has its own uniqueness. There is an era in which all forms of knowledge must be memorized. However, after the advent of the printing press, many books circulated that could be a source of knowledge. And after this post-modern era arrives, all knowledge is available at hand via smart-phone at any time.According to historical records, education in the Jewish tradition is very strict. From an early age, a human child has been accustomed to remember what has been learned as part of life. There are four records in history to understand the practice of learning in understanding God's Law carefully and memorizing it. These sources from different eras testify simultaneously that memorization is a must for Jewish education context both at home, public school and synagogue. The sectarian, in Qumran, maintained their own strict interpretation of the Law. Family was still the chief institution and primary context for the dispensation of elementary instruction; although the scribes, Pharisees and learned rabbis played a major role in Jewish education during the NT era. Talmud is more specific about the age of studying and the sign of mastering. Origen also was trained since his childhood by his father, Leonides, to memorize Scripture daily and recite them every day.
\end{abstract}

Keywords: Dead Sea Scrolls, New Testament, Talmud, Patristic'Document 


\section{Dead Sea Scrolls ${ }^{1}$}

The sectarian, in Qumran, 2 maintained their own strict interpretation of the Law. ${ }^{3}$ They were also compelled to know this Law off by heart (1QS V.21, 23, VI. 18). Apocalypse of Baruch records that, for instance, God says, "Listen, Baruch, to this word and write down in the memory of your heart all that you shall learn" (2 Baruch 50:1). 4Q88 VII (=11Q5 XXIII) says, "May your memory be blessed forever!" 4 In

${ }^{1}$ For text, see Florentino Garcia Martinez and Eibert
J. C. Tighelaar, The Dead Sea Scrolls Study Edition,
Netherlands, Leiden: Brill: 1997 .
${ }^{2}$ The Jews of Qumran were called simply yahad,
"community" (1QS1.1,12,16), or harabbîm, "the Many" (1QS 6.1,8,11), or even "the Way" (1QS $9.17-18,21)$. Members who joined the community were said to "enter the covenant" (1QS 1.18, 20). Chosen by divine predilection, they were the remnant of Israel (CD 1.4), the new Temple (1QS8.5), the new plantation (1QS 11.8), the new people of God (1QM 1.5; 3.13), with whom He made a "new covenant" (CD 6.9; 20.12; cf. Jer 31.31). Their retreat to the desert was motivated by Is 40.3 , "to prepare the way of the Lord" (1QS 8.14-15).

${ }^{3}$ They lived an ascetic life, nourished by common work, prayer, study and interpretation of the Torah and the Prophets, strict observance of Levitical purity regulations, and a conviction that it was already the "end of days" (1Qp Hab 2.5; 9.6). Two rites formed the main cultic exercises of daily life: purificatory washings and a common religious meal. Regarding to purificatory washings, the members of the Community stopped working to purify themselves through immersion in ritual baths (miqva'ot) as noon approached. This is a necessary condition for participation in the communal meal. The finds from Qumran provide further evidence of the importance of purity to the sectarians. Scholars hold that the so-called "measuring cups" made of stone, which is not susceptible to impurity according to Jewish law, were used mainly for ritual hand washing. A mattock found in one of the caves brings to mind Josephus's report that the Essenes used a special tool to dig a deep hole in the ground, into which they relieved themselves, believing that feces defiled the body (Jewish War II, viii, 9). After summary, this group also exhorted to watch God's Law carefully and memorize it by heart.

\section{New Testament}

Family was still the chief institution and primary context for the dispensation of elementary instruction; although the scribes, ${ }^{5}$ Pharisees ${ }^{6}$ and learned rabbis played a major role in Jewish education during the NT era. ${ }^{7}$ The teachers in

purifying themselves through ritual immersion, the sectarians crowded into a special hall for a communal meal. It is recorded by Josephus, "After this purification, they assemble in a private apartment ... pure now themselves, they repair to the refectory, as to some sacred shrine" (Jewish War II, viii, 5). See also https://www.britannica.com/topic/Qumrancommunity;

4 The context is discussing congregation memory about hope and expectation of Israel' salvation from God. The exhortation to remember God's law appears in other writing such as 4Q197 12, "Do you not remember the precepts of your father who commanded you to take a wife from your father's house?"; 4Q219 I 13, "I have been remembering our God always and I sought him with all my heart".

${ }^{5}$ Scribes are men specially trained in writing, and thus influential as interpreters and teachers of the Law, and agents of the rulers.

6 "Pharisees" probably means "separated ones" in Hebrew, referring to their strict observance of laws and traditions (Luke 18:10-12). Mostly laymen, but possibly also some priests (from the tribe of Levi) or even members of the Sanhedrin (Acts 5:34). The leaders were called "rabbis" or "teachers", such as Nicodemus (John 3:1-10; 7:50; 19:39) and Gamaliel (Acts 5:34; 22:3).

7 The synagogue apparently came into existence during the Babylonian captivity when the Jews were deprived of the services of the Temple. During captivity they began meeting in small groups for prayer and Scripture reading. When they returned to Israel the synagogue spread rapidly and developed into an important educational institution. Synagogue services made an important educational contribution to the religious life of the community. The 
synagogue taught the students about the Scripture (Lu. 2:46-47), reading, writing and arithmetic by using memorization, drill and review were used as approaches to teaching.

However, if someone wanted training beyond that given in a synagogue, he would go to a scholarly scribe. Saul of Tarsus received such advanced theological training "at the feet of Gamaliel" in Jerusalem (Acts 22:3). Public elementary schools grew slowly until the time of Joshua ben Gamala, a high priest from 63-65 $\mathrm{AD}$.

He ordered that the teachers should be appointed in every province and city to instruct children having attained the age of 6-7 years. ${ }^{8}$ The teachers still emphasized the importance of memorization: the exact

elementary school system among the Jews developed in connection with the synagogue. Even before the days of Jesus, schools for the young were located in practically every important Jewish community. Boys usually began formal schooling at the "house of the book" at age five. He would spend at least a half day, six days a week for about five years, studying at the synagogue. Parents brought their son at daybreak and came for him at midday. While not at school the boy was usually learning a trade, such as farming or carpentry. See Holman Bible Dictionary.

8 There were two types of Torah school in Judaism; bet sefer and bet hammidrash. Bet sefer, as its name implies, is a school of scripture. The teacher is the one who is familiar with the art of writing, with books, and with the holy books in particular. It is certain, therefore, certain that some individual soferim were able to pass on solid and many-sided teaching in Torah. See ISBE Bible Dictionary.

${ }^{9}$ Ibid.

${ }^{10}$ Judaism believes that God revealed the Torah to Moses in two media, written and oral, with the written part corresponding to the Pentateuch, a further, oral part of the Torah is included in the reproduction by the pupil of the master's teaching. ${ }^{9}$ In conclusion, memorization was still the main objective of Jewish education in family, synagogue and public elementary school.

\section{Talmud ${ }^{10}$}

Talmud is more specific about the age of studying and the sign of mastering. A child's education commences when he begins to speak, ${ }^{11}$ whereupon the duty devolves upon the father to teach him to repeat selected biblical verses, such as "Moses commanded us a law, an inheritance of the congregation of Jacob" (Deut. 33:4). 12 Talmudic literature makes it plain in many ways that the children had to learn Scripture texts by heart. ${ }^{13}$ The teachers and others also test the children's capabilities by asking

meanings Jews assign to the word. This oral part is held to encompass the teachings ultimately written down by the sages of the Torah in ancient times and is contained, in part, in the Mishnah, Talmud, and Midrash-complations. See Jacob Neusner, Torah in Judaism in The Encyclopedia of Judaism, Vol III P$Z$, ed. Jacob Neusner, Alan J. Avery-Peck, William Scott Green (Leiden: Brill NV, 2000), 1447.

11 This reveals the sage' appreciation of the cultivation of a child's imitative, mechanical faculties even before the attainment of understanding.

${ }^{12}$ Yagod, 'Tradition', 170.

${ }^{13}$ If pedagogical rule in Judah b. Tema was rigidly adhered to, the children would be able to memorize, have proficiency in recitation and knowledge of the Bible and mizvot; even participate in the creative study of Talmud by the age of fifteen. As it is recorded: "at five years the age is reached for studying the Bible, at seven for studying the Mishnah, at thirteen for fulling the mitzvot, at fifteen for studying the Talmud" (Avot 5:21). Therefore, the Talmudic literature bears witness to their unequalled memory-knowledge of the written texts. Moreover, 
them to read out loud (from memory). In terms of punishments, discipline played a vital role in this education system. The teachers would not hesitate to inflict corporal punishment when deemed necessary. ${ }^{14}$

It implies Jewish education highly considers mastering of oral tradition because there is punishment for those who are not able to repeat what they memorized. In summary, Talmud reveals the importance of memorization not only through the early age of the children, but also corporal punishments as the part of education.

\section{Patristic' Document}

Eusebius recorded that Polycarp listened attentively and memorized Jesus' words and miracles from apostle John by heart. Afterwards, he keeps memorizing them continually, recalls them faithfully and makes an introductory formula, "remembering what the Lord taught when he said" (Eus. Church History Book 5, 20:67; Polycarp to the Philippians 2:3). ${ }^{15}$

Origen also was trained since his childhood by his father, Leonides, to memorize Scripture daily and recite them every day (Eus. Church History Book 6, 2:7-9). ${ }^{16}$ Papias mentioned that he has learned carefully from the elders and carefully remembered to guarantee their truth (Eus. Church History Book 3, 39:3-5).

17 Papias uses Mark as an example; how

had made them a matter of no secondary importance. 8. First of all, before inducting him into the Greek sciences, he drilled him in sacred studies, requiring him to learn and recite every day. 9. Nor was this irksome to the boy, but he was eager and diligent in these studies. And he was not satisfied with learning what was simple and obvious in the sacred words, but sought for something more, and even at that age busied himself with deeper speculations. So that he puzzled his father with inquiries for the true meaning of the inspired Scriptures. 10. And his father rebuked him seemingly to his face, telling him not to search beyond his age, or further than the manifest meaning. But by himself he rejoiced greatly and thanked God, the author of all good, that he had deemed him worthy to be the father of such a child.

17 3. He says: But I shall not hesitate also to put down for you along with my interpretations whatsoever things I have at any time learned carefully from the elders and carefully remembered, guaranteeing their truth. For I did not, like the multitude, take pleasure 
Mark faithfully remembers the things said or done by Christ through peter and committed no error while he wrote some things as he remembered them (Eus. Church History Book 3, 39:15). ${ }^{18} 1$ Clement also emphasizes the importance of remembrance of the words and deeds of our Lord Jesus Christ (1 Clement 46:7). ${ }^{19}$ In conclusion, Church Fathers reiterate that memorization plays an important role of education.

\section{Summary}

These sources from different eras testify simultaneously that memorization is a must for Jewish education context both at home, public school and synagogue. The evidences reveal that people, who lived in

in those that speak much, but in those that teach the truth; not in those that relate strange commandments, but in those that deliver the commandments given by the Lord to faith, and springing from the truth itself. 4. If, then, any one came, who had been a follower of the elders, I questioned him in regard to the words of the elders - what Andrew or what Peter said, or what was said by Philip, or by Thomas, or by James, or by John, or by Matthew, or by any other of the disciples of the Lord, and what things Aristion and the presbyter John, the disciples of the Lord, say. For I did not think that what was to be gotten from the books would profit me as much as what came from the living and abiding voice. 5 . It is worth while observing here that the name John is twice enumerated by him. The first one he mentions in connection with Peter and James and Matthew and the rest of the apostles, clearly meaning the evangelist; but the other John he mentions after an interval, and places him among others outside of the number of the apostles, putting Aristion before him, and he distinctly calls him a presbyter.

18 15. This also the presbyter said: Mark, having become the interpreter of Peter, wrote down accurately, though not in order, whatsoever he remembered of the things said or done by Christ. For these eras, were proficient to recite the Scripture continually and faithfully (read: as soon as possible to the Scripture) since they were young.

\section{REFERENCES}

[1] Alexander, Philip S., "Jewish Aramaic translations of Hebrew Scriptures" in Mikra (1988): 217-253.

[2] Andersen, Ø. “Oral Tradition,” in Jesus and the Oral Gospel Tradition. Edited by H. Wansbrough. Sheffield: Sheffield Academic, 1991.

[3] Baddeley, Alan D. Human Memory: Theory and Practice. UK: Psychology Press Ltd, Publishers, 2002.

[4] Bailey, Kenneth E. "Informal Controlled

he neither heard the Lord nor followed him, but afterward, as I said, he followed Peter, who adapted his teaching to the needs of his hearers, but with no intention of giving a connected account of the Lord's discourses, so that Mark committed no error while he thus wrote some things as he remembered them. For he was careful of one thing, not to commit any of the things which he had heard, and not to state any of them falsely. These things are related by Papias concerning Mark. Compare to Eusebius Church History 6, 14:6, "The Gospels containing the genealogies, he says, were written first. The Gospel according to Mark had this occasion. As Peter had preached the Word publicly at Rome, and declared the Gospel by the Spirit, many who were present requested that Mark, who had followed him for a long time and remembered his sayings, should write them out. And having composed the Gospel he gave it to those who had requested it."

${ }^{19}$ Why do we divide and tear to pieces the members of Christ, and raise up strife against our own body, and have reached such a height of madness as to forget that we are members one of another? Remember the words of our Lord Jesus Christ, $(1 \mathrm{Cl}$ 46:7) 
Oral Tradition and the Synoptic Gospels", AJT 5:1

(1991): 34-54.

[5] Carson, D. A. and Douglas J. Moo. An Introduction to the New Testament 2nd edition. Grand

Rapids, Michigan: Zondervan, 2005.

[6] Chia, P. S., \& Juanda, J. (2020).

Understanding The Relationship Between Faith and Knowledge. Journal DIDASKALIA, 3(1), 1-6.

[7] Dunn, James. Jesus Remembered. Grand Rapids, Michigan: William B. Eerdmans Publishing

Company, 2003.

[8] Ehrman, Barth D. Jesus Before the Gospels. New York: HarperCollins Publisher Inc., 2016.

[9] Eusebius Church History Book 3. http://www.newadvent.org/fathers/250103. htm

[10] Eusebius Church History Book 5. http://www.newadvent.org/fathers/250105. htm

[11] Eusebius Church History Book 6. http://www.newadvent.org/fathers/250106. htm

[12] Polycarp to the Philippians. [Computer Software; Bibleworks 9]

[13] 1 Clement. [Computer Software; Bibleworks 9]

[14] Friston, K. J. ‘Analyzing brain images:
Principles and overview' in Human Brain Function.

Edited by R. S. J. Frackowiak, K. J. Friston, C. D. Frith, R. J. J. Dolan, \& J. C. Mazziotta. Toronto: Academic Press, 1997.

[15] Gerhardson, Birger. Memory and Manuscript. Copenhagen: Willadsen of Christensen, 1964.

[16] Kirk, Alan, and Tom Thatcher. Memory, Tradition and Text. Atlanta: Society of Biblical

Literature, 2005.

[17] Martinez, Florentino Garcia and Eibert J. C. Tighelaar. The Dead Sea Scrolls Study Edition.

Netherlands, Leiden: Brill: 1997.

[18] Neusner, Jacob. Torah in Judaism in The Encyclopedia of Judaism, Vol III P-Z. Edited by Jacob Neusner, Alan J. AveryPeck, William Scott Green. Leiden: Brill NV, 2000.

[19] Riesner, Rainer. "Jesus as Preacher and Teacher" in Jesus and the Oral Gospel Tradition. Edited by Henry Wansbrough. England: Sheffield Academic Press, 1991. [20] Yagod, Leon J. Tradition in Encyclopaedia JUDAICA, 2nd edition, Vol. 6: DR-FEU. Edited by Fred Skolnik and Michael Berenbaum. Farmington Hills, MI: Macmillan Reference USA, Thomson Gale, 2007.

[21] Houtman, Alberdina, and Harry Sysling. Alternative Targum Tradition: The Use of Variant

Readings for the Study in Origin and History of Targum Jonathan. Netherlands: Brill, 2009. 